\title{
VARIABILITY, HERITABILITY AND GENETIC ADVANCE FOR YIELD AND YIELD CONTRIBUTING CHARACTERS IN TOMATO (Lycopersicon esculentum Mill.)
}

\author{
M. S. R. Khanom, M. H. K. Khan ${ }^{1}$ and L. Hassan \\ Dept. of Genetics and Plant Breeding, Bangladesh Agricultural University \\ Mymensingh-2202, Bangladesh
}

\begin{abstract}
The experiment was conducted during rabi season, 2003-2004 at the Field Laboratory of the Department of Genetics and Plant Breeding, Bangladesh Agricultural University, Mymensingh. Genotypic variability, heritability and genetic advance for yield and yield contributing characters were studied on 55 tomato genotypes. Data were recorded on number of primary branches per plant, days to first flowering, plant height, number of bunches per plant, number of fruits per plant, individual fruit weight, number of seeds per fruit, dry matter content of fruits, $\mathrm{pH}$ level of fruit juice and yield per plant. Very little differences were observed between genotypic coefficient of variation and phenotypic coefficient of variation for all the characters except dry matter content and yield per plant indicating that they were less influenced to environmental factors for their phenotypic expression. High heritability estimates coupled with high genetic advance in percentage of mean were obtained for number of primary branches per plant, number of days to first flowering, plant height, number of bunches per plant, number of fruits per plant, individual fruit weight and number of seeds per fruit indicating wide scope for improvement through selection of these traits.
\end{abstract}

Key words : Variability, Heritability, Genetic advance, Tomato

\section{INTRODUCTION}

Tomato is a major vegetable crop that has achieved tremendous popularity throughout the world for its taste and nutritive value. It is the third major vegetable of Bangladesh grown mainly during the winter season in open fields. Though the cultivation of tomato has been getting more popularity among the vegetable growers of Bangladesh in recent years, its per unit area production is very low $(6.47 \mathrm{mt} / \mathrm{ha})$ comparing to those of leading tomato producing countries of the world (FAO, 2003). On the other hand, arable land is becoming very scarce in this densely populated country. So, it is very important to develop high yielding varieties of tomato to cope with the ever increasing demand. Considerable research works have been done in different countries resulting in the development of numerous varieties of tomato (Brar et al., 2000). But, very limited works on selective breeding of tomato have been initiated in Bangladesh. Hence, there is a need to intensify research efforts in this area for enhancement of production of tomato.

\footnotetext{
1 Upazila Fisheries Officer, Barhatta, Netrakona, Bangladesh
} 
The basic key to bring about genetic improvement to a crop is to utilize the available or created genetic variability. If the variability in the population is largely due to genetic cause with least environmental effect, the probability of isolating superior genotype is possible. As yield of tomato fruits is a polygenic character and is associated with many agronomic, morphological and physiological traits, so direct selection for yield may be often misleading. The progress of breeding in such a population is primarily conditioned by magnitude, nature and interaction of genotypic and environmental variation in the various plant characters. It then becomes necessary to partition the observed variability into heritable and non-heritable components with the help of suitable genetic parameters such as genotypic co-efficient of variation, heritability estimates and genetic advance etc. The characters showing high heritability along with high estimates of genetic advance are more effective for selection (Kalloo, 1985). So, the present study was undertaken to explore the characters highly responsible for the yield of tomato by estimating variability, heritability and genetic advance of different characters.

\section{MATERIALS AND METHODS}

The experimental materials comprised of 55 genotypes of tomato of which 35 were taken from Bangladesh Agricultural University (BAU), 11 from Bangladesh Agricultural Research Institute (BARI), 7 from Asian Vegetables Research and Development Centre (AVRDC), one from Bangabandhu Sheikh Mujibur Rahman Agricultural University (BSMRAU) and one from Bangladesh Institute of Nuclear Agriculture (BINA). The experiment was conducted in a randomized complete block design with three replications each at the Field Laboratory of the Department of Genetics and Plant Breeding, BAU during rabi season 2003-2004. Plot size was 3.0 sq. m. (2.5m X 1.2m) each. Row to row distance was $60 \mathrm{~cm}$ and plant to plant distance was $50 \mathrm{~cm}$. Standard agronomic practices were followed whenever necessary.

Parameters studied in the experiment were number of primary branches per plant, number of days to first flowering, plant height, number of bunches per plant, number of fruits per plant, individual fruit weight, number of seeds per fruit, dry matter content, $\mathrm{pH}$ level of ripe fruits and yield per plant. Data were recorded on an individual plant basis from three randomly selected plants per genotype in a replicate. Out of the ten characters chosen for study, data on number of primary branches per plant, number of days to first flowering, plant height and number of bunches per plant were recorded in the field conditions. The remaining characters were recorded in the laboratory conditions after harvest. Genotypic coefficient of variation (GCV) and phenotypic coefficient of variation (PCV) were estimated by the formula of Singh and Chaudhury (1985). Heritability in broad sense was estimated according to the method of Johnson et al. (1955). In order to assess genetic advance, the formula of Johnson et al. (1955) was used. The genetic advance in percentage of mean was calculated by the formula used by Comstock and Robinson (1952). 


\section{RESULTS AND DISCUSSION}

\section{Variability}

The characters- plant height, number of branches and fruits per plant, individual fruit weight and number of seeds per fruit showed comparatively high genotypic and phenotypic coefficient of variation. Genotypic coefficient of variation (GCV) of all the characters varied between 2.494 and 31.473 while phenotypic coefficient of variation (PCV) ranged between 4.930 and 33.484 (Table 1). Very little differences between GCV and PCV were observed for all the characters except dry matter content and yield per plant indicating that there was little influence of environmental factors on their phenotypic expression. Dry matter content and yield per plant obtained relatively higher values for PCV than that of GCV suggesting that yield of tomato is vulnerable to environmental fluctuations. Similar results for the differences between GCV and PCV were observed by Brar et al. (2000) for number of fruits per plant; by Islam and Khan (1991) for plant height; by Matin (2001) for number of seeds per fruit and yield per plant.

Table 1. Genetic parameters of ten different characters of 55 tomato genotypes

\begin{tabular}{l|c|c|c|c|c|c}
\hline \multirow{2}{*}{ Characters } & \multicolumn{5}{|c}{ Genetic parameters } \\
\cline { 2 - 7 } & Mean \pm SE & $\begin{array}{c}\text { Genotypic } \\
\text { co-efficient } \\
\text { of variation } \\
(\%)\end{array}$ & $\begin{array}{c}\text { Phenotypic } \\
\text { co-efficient } \\
\text { of variation } \\
(\%)\end{array}$ & $\begin{array}{c}\text { Heritability } \\
(\%)\end{array}$ & $\begin{array}{c}\text { Genetic } \\
\text { advance }\end{array}$ & $\begin{array}{c}\text { Genetic } \\
\text { advance in } \\
\text { percentage } \\
\text { of mean }\end{array}$ \\
\hline $\begin{array}{l}\text { Number of primary } \\
\text { branches per plant }\end{array}$ & $6.028 \pm 0.092$ & 21.750 & 24.488 & 78.489 & 2.399 & 39.760 \\
$\begin{array}{l}\text { Days to first } \\
\text { flowering }\end{array}$ & $53.174 \pm 0.329$ & 11.151 & 12.056 & 85.560 & 11.299 & 21.248 \\
$\begin{array}{l}\text { Plant height } \\
\text { Number of bunches }\end{array}$ & $7.275 \pm 0.120$ & 24.396 & 26.831 & 82.677 & 3.324 & 45.696 \\
per plant & $41.247 \pm 1.214$ & 29.495 & 32.088 & 84.495 & 39.792 & 55.851 \\
$\begin{array}{l}\text { Number of fruits } \\
\text { per plant }\end{array}$ & $41.284 \pm 0.688$ & 20.009 & 23.519 & 72.381 & 14.478 & 35.068 \\
$\begin{array}{l}\text { Individual fruit } \\
\text { weight }\end{array}$ & $45.706 \pm 0.704$ & 31.473 & 33.484 & 88.350 & 27.853 & 60.941 \\
$\begin{array}{l}\text { Number of seeds } \\
\text { per fruit }\end{array}$ & $90.466 \pm 1.234$ & 23.700 & 25.767 & 84.600 & 40.624 & 44.905 \\
$\begin{array}{l}\text { Dry matter content } \\
\text { pH }\end{array}$ & $5.163 \pm 0.090$ & 5.713 & 14.061 & 16.509 & 0.247 & 4.781 \\
$\begin{array}{l}\text { Yield per plant } \\
\text { Y }\end{array}$ & $1.794 \pm 0.039$ & 15.060 & 22.087 & 46.497 & 0.380 & 21.155 \\
\hline
\end{tabular}




\section{Heritability and genetic advance}

The highest value of heritability was observed for individual fruit weight followed by number of days to first flowering and number of seeds per fruit, while the lowest value was found for dry matter content of tomato fruits (Table 1). Although high heritability estimates have been found to be helpful in making selection of superior genotypes on the basis of phenotypic performance, Johnson et al. (1955) suggested that heritability estimates along with genetic gain were more useful in predicting selection of the best individual. High heritability estimates coupled with high genetic advance in percentage of mean for number of primary branches per plant, number of days to first flowering, plant height, number of bunches per plant, number of fruits per plant, individual fruit weight and number of seeds per fruit were obtained suggesting a wide scope for improvement through selection of these traits.

The quality characters like $\mathrm{pH}$ and dry matter content of tomato fruits exhibited very low values of heritability and genetic advance in percentage of mean. Moreover GCV and PCV for these characters were low. This suggests that selection for these two quality characters would not be effective. Matin (2001) also obtained low values of genetic advance for $\mathrm{pH}$ while Kasrawi and Amr (1990) observed high values of heritability and genetic advance which is not similar to the findings of the present study. Besides, number of days to first flowering and yield per plant showed high to moderate heritability associated with moderate genetic gain the scope of improvement of this character by direct selection would be limited. Matin (2001) found moderate value of heritability with low genetic advance for number of days to first flowering which is not supported by present study. This variation might be due to high macro environmental influence in flowering tomato. Similar results were obtained by Das et al. (1998) for number of fruits per plant; and Sidhu and Singh (1989) for average fruit weight.

\section{REFERENCES}

Brar, G. S., Singh, S., Cheema, D. S., Dhaliwal, M. S. and Singh, S. 2000. Studies on variability, heritability and genetic advance for yield and component characters in tomato (Lycopersicon esculentum Mill.). J. Res., Punjab Agricultural University. 37(3-4): 190-193.

Comstock, R. E. and Robinson, H. F.1952. Genetic parameters, their estimation and significance. Proc. $6^{\text {th }}$ Intl. Grassland Cong., 1: 284-291.

Das, B., Hazarika, M. H. and Das, P. K. 1998. Genetic variability and correlation in fruit character of tomato (Lycopersicon esculentum Mill.). Annals Agril. Res., 19(1): 77-80.

FAO (Food and Agriculture Organization). 2003. FAO Production Year Book. Basic Data Unit, Statistics Division, FAO, Rome, Italy. 57: 140-141..

Islam, M. S. and Khan, S. 1991. Variability and character association in tomato (Lycopersicon esculentum Mill.). Bangladesh J. Plant. Breed. Genet., 4(1-2): 49-53.

Johnson, H. W., Robinson, H. F. and Comstock, R. E.1955. Estimates of genetic and environmental variability in soyabeans. Agron. J., 47(7): 314-318. 
Kalloo. 1985. Tomato (Lycopersicon esculentum Miller). Allied Publishers Pvt. Ltd., India. p. 407.

Kasrawi, M. A. and Amr, A. S. 1990. Genotypic variation and correlation for quality characteristics in processing tomatoes. J. Genet. Breed., 44(2): 85-89.

Matin, M. A. 2001. Study on the variability, interrelationship of agro-morphological and some qualitative characters of tomato. A thesis submitted to the Department of Genetics and Plant Breeding, Bangladesh Agricultural University, Mymensingh in partial fulfillment of Master of Science degree.

Sidhu, A. S. and Singh, S. 1989. Genetic variability and correlation for yield and quality characters in tomato (Lycopersicon esculentum). Indian J. Agric. Sci., 59(12): 810-812.

Singh, R. K. and Chaudhury, B. D. 1985. Biometrical Methods in Qualitative Genetic Analysis (Rev. edition). Kalyani Publishers, New Delhi, India. 